\title{
The Making Stage of the Modern Palestinian Arabic Novel in the Experiences of the udabā' Khalīl Baydas (1874-1949) and Iskandar al-Khūri al-BeitJāli (1890-1973)
}

\author{
Sadia Agsous
}

\section{A Cultural Life Before Its Destruction}

It is quite common nowadays to read articles or gaze at photographs representing a vibrant Palestinian cultural life before the destruction of historical Palestine in 1948 referred to as Nakba (Arabic for "Catastrophe"). In her documentary Looking for Zion, ${ }^{1}$ the Israeli filmmaker Tamara Erde includes the photo studio of Karimeh Abbud (1896-1955), the first female photographer in Palestine and the wider region, who signed her work as a "LadyPhotographer". A native of Nazareth, as early as the 1920s Abbud captured families, mostly women and children, weddings and ceremonies in places such as Haifa, Nazareth and Bethlehem, and archaeological sites. ${ }^{2}$ Her name and work stand out alongside those of other photographers such as Fadil Saba (1901-1988) of Nazareth, Khalīl Raad (1891-1948) of Jerusalem and Issa Sawabini and Daoud Sabonji of Jaffa, names considered to be those of the

\footnotetext{
${ }^{1}$ Erde, Tamara. Looking for Zion. Film by Katuh Studio and 13 Productions. http://www. film-documentaire.fr/4DACTION/w_fiche_film/52690_1.

${ }^{2}$ Ahmed Mrowat, "Karimeh Abbud: Early Woman Photographer (1896-1955)," Jerusalem Quarterly 31 (2007): 72-78.
}

S. Agsous $(\bowtie)$

L'Institut de Recherches et d'Études sur les Mondes Arabes et Musulmans (Iremam), Paris, France 
founders of local photography. ${ }^{3}$ The first cinema, The Oracle, was inaugurated in Jerusalem in 1908 by Egyptians, ${ }^{4}$ and music as well as theatre had their own spaces. It is well known that in 1935 Umm Kulthum attracted audiences from all corners of Palestine for her historical concert at the al-Hamra (Alhambra) Theatre in Jaffa. ${ }^{5}$ The Al-Hamra also hosted famous Arab singers such as Farid el-Atrash and Leila Mourad. ${ }^{6}$ The Apollo and the Nabil were the scenes of other types of cultural evenings (cinema, theatre, music...). ${ }^{7}$ Between 1945 and 1948, Jaffa was under the administration of Yusuf Haykal (1907-1989), a leading intellectual who tried to perpetuate this Palestinian space within a framework of modernisation planning and competition with the recently established Jewish city of Tel Aviv.

The Palestinian oral cultural repertoire (music, dance, poetry) was rich and the establishment of an Arabic Radio programme became an important tool for its diffusion and modernisation. This was the role undertaken by the Palestine Broadcasting Service ${ }^{8}$ and its Arabic programming, Iza'at al Quds, established in 1936 by the Mandate authorities and reflecting the cultural side of a large space which went beyond Palestine: "Palestine was clearly an important passageway for musicians travelling between Egypt and the Levant; they held concerts in Jerusalem, Jaffa, and other Palestinian cities and influenced musicians in those regions." 9 The memoirs of Wasif Jawhariyyeh (1897-1973), a native of Jerusalem, provide us with a vibrant account of the city of Jerusalem as it underwent a process of modernisation, ${ }^{10}$ as well as

\footnotetext{
${ }^{3}$ Noa Sadka, Photographic Truth is a Natural Truth-A Chronicle of a Photography Department (Tel Aviv: Resling, 2018), 364. (In Hebrew).

${ }^{4}$ Mohammed Omar Jahjooh and Omar Ismail, The Palestinians' Cinema: History...and Identity (Ramallah: Tibaq Publishing, 2018), 188.

${ }^{5}$ Oum Kulthum visited Palestine in 1931 and 1935 and performed in Jaffa, Haifa and Jerusalem.
}

${ }^{6} \mathrm{With}$ its printing houses, theatres, cinemas, radio and press, Egypt was an important modern Arab cultural centre. The city was a hub for Arab intellectuals, including Palestinians, creating Egyptian influence in the region and in Palestine particularly in the field of music and cinema.

${ }^{7}$ Itmar Radai, Palestinians in Jerusalem and Jaffa, 1948 (London: Routledge, 2016), 224.

${ }^{8}$ Jerusalem Calling (1936-1948) was the name of the English-language programmes broadcast by the British Mandate Authority's Palestine Broadcasting Service. It also broadcast in Arabic and Hebrew (Kol Yerushalayim). The Arabic programme was headed by the poet Ibrahim Tuqan (1905-1941).

${ }^{9}$ Souhail Khoury, "Palestinian Music, Blending Levantine Sounds and the Power of Poetry," https://www.paljourneys.org/en/timeline/highlight/10526/palestinian-music.

${ }^{10}$ The modernity mentioned by Salim Tamari relates to the city of Jerusalem at the end of its Ottoman period from a spatial and cultural point of view. In his memoirs, the musician Wasif Jawhariyyeh reports the expansion of Jerusalem outside the walls of the old city and into districts such as Musrara, Mascobiyyeh, Talbieh, Katamon and Bakaa, where families such as Baydas and Sakakini lived in modern houses. These neighborhoods were also crossed by a railway and modern roads. As for the modernisation of Arabic music, Tamari explains that "Jawhariyyeh's observations provide us with an original and unique source on the modernization of Arabic music in Bilad al-Sham and the influence of such great innovators as Sheikh Yusif al-Minyalawi and Sayyid Darwish on provincial capitals like Jerusalem. In his musical notes, written before the end 
of his own musical practice. Western music, particularly classical music, was introduced with the missionary schools and religious institutions. Among its Palestinians pioneers were Augustin Lama (1901-1988), born in Ramleh to a family from Bethlehem, and his students Salvador Arnita (1914-1984), a native of Jerusalem and the last music director of the YMCA, and Yousef Khasho (1927-1996), who was born in Jerusalem and at a very young age played the organ for the Choir of the Church of the Holy Sepulchre. Thanks to the radio station, important musicians like Yahya al-Libabidi (1900-1941), who ran the Arabic music division of Radio Palestine, Rawhi al-Khammash (1923-1998), Mohamed Ghazi (1922-1979), Yahya al-Saudi (1905-1965) and Riad al-Bandak (1924-1992) became well known.

Theatre was also part of this cultural ferment and was performed in Haifa's Orthodox, Catholic and Islamic Clubs as well as those of other cities in Palestine. ${ }^{11}$ Plays were performed in cafés and clubs; the most renowned figures in this field are the Saliba brothers, Jameel Habib Bahry, the Nasri brothers, and Jameel al-Jawzi. This theatrical vibe was described by the Palestinian writer Emile Habiby (1922-1996) with a take on the cultural movement between Palestine and the rest of the region:

(...) There were the El-Juzee brothers, who I remember very well. Some of the theatres also used to use the clubs for a base, such as the Orthodox Club in Haifa and the Moslem Youth Club in Jaffa (...) We brought singers over from Lebanon too, and writers and poets from Iraq. The Radio Broadcasting service played an important role. During Ramadan evenings there were suitable broadcasts on the radio, and the Palestinian community here used to bring artists from different Arab countries to celebrate Ramadan evenings, in cinemas and cafes. $^{12}$

\section{Literature, Nahda and Russian Schools in Palestine}

Literature and translations were also important activities during the British Mandate in Palestine (repealed on 15 May 1948). In the year 1946, two years prior to the Nakba, the newspaper Falastin celebrated the first Palestinian Arab book fair with the title "The Palestinian Arab Book Fair: worthy efforts for our cultural Nabda". This exhibition was the outcome of efforts by the Arab Cultural Committee under the leadership of Abdel Hamid Yacine

of the war in 1918, Jawhariyyeh devised a notation procedure to convert the Arabic-Ottoman quarter-note system for the "oud into the Western system of musical notations" (Salim Tamari, "Jerusalem's Ottoman Modernity: The Times and Lives of Wasif Jawhariyyeh," Jerusalem Quarterly 9 [2000]: 500).

${ }^{11}$ Marie Elias, "Palestinian Theater, the Bumpy History of a Maturing Art," https://www.paljourneys.org/en/timeline/highlight/10520/palestinian-theater.

${ }^{12}$ Sihem Daoud, "Interview with Emil Habibi," Contemporary Theater Review 3, part 2 (1995): 103-112. 
(1908-1975), a writer and educator born in al-Lydd (Lod) and one of the directors of the Arabic radio programme Iza'at al Quds; Nicolas Ryadeh (1907-2006), a historian who was one of the founders of the Orthodox Club in Acre in 1929; and Ishaq Musa al-Husayni (1904-1990), the General Secretary of the Arab Cultural Committee in Palestine, ${ }^{13}$ best known for his 1943 novel Memoirs of a Hen (مذّكرات دجاجة). Falastin proudly displayed the names of the authors and intellectuals who had given meaning to this Palestinian culture in its existing state:

What is remarkable about this exhibition is that Khalil Baydas' forty-four books, three manuscripts and the printed remnants, represented the largest number of books produced by a single author. Then comes Professor Ahmad Sameh al-Khalidi with twenty books, followed by Mr. Khalīl Sakakini with eleven (...) If we cannot neglect Dr. Tawfiq Kanan's works, we are attracted by its linguistic and content diversity. about forty books and letters were exhibited, some of which are written in Arabic, French and English and covers popular literature and medicine. ${ }^{14}$

Falastin used the term Nabda to reflect the local cultural renaissance which began at the end of the nineteenth century. To position this Arab renaissance in its larger Arab temporality, Nabda refers to the Arab project of cultural and political modernity set between the early nineteenth and early twentieth centuries. It is also a period in which new aesthetic directions emerged. As Tarek el-Ariss puts it, "Arab models of nationalism and secularism as well as Islamic revival are attributed to Nahda thought and institutions such as linguistic reform and the practice of translation; the emergence of new literary genres such as the novel; the periodical press, journalism, and new publishing industry (...)."15

As far as the Palestinian situation is concerned, the period of the Palestinian Nabda is situated chronologically at the end of the broader Arab Nabda, i.e. the end of the nineteenth and the beginning of the twentieth centuries. In this respect, it fits with what Rashid Khalidi describes as "The shift from the Arab/Ottoman to Palestinian Arab-Identity" 16 and highlights the emergence of Palestinian national consciousness in opposition to the Ottomans, the British and the Zionist project in Palestine. Culture has clearly played a key position, but one has to question whether it was achieved by

\footnotetext{
${ }^{13}$ Launched in 1945, the Arab Cultural Committee in Palestine organised cultural events in major cities of Palestine in connection with different cultural Arab centres. Ilan Pappe, The Rise and Fall of a Palestinian Dynasty: The Husaynis 1700-1948 (Berkeley: University of California Press, 2010), 400.

${ }^{14}$ Falastin vol. XXX, nos. 180-6435 (10.10.46). (In Arabic).

${ }^{15}$ Tarek El-Ariss, The Arab Renaissance: A Bilingual Anthology of the Nabda (New York: The Modern Language Association of America; Bilingual edition, 2018), xvi.

${ }^{16}$ Rashid Khalidi, Palestinian Identity: the construction of Modern National Consciousness (New York: Columbia University Press, 2010), 8.
} 
copying the European colonial cultural model, or in the perspective of a cultural construction that goes hand in hand with national formation. The factors outlined above suggest that both elements should be considered.

Hanna Abu Hanna stresses a correlation between the establishment of European Christian missionary schools, particularly the Russian ones aimed at the Greek orthodox communities, and the process of the Arab cultural and literary Nahda. ${ }^{17}$ Indeed, several ûdabâ attended these Russian institutions, including Elia Zakka, the founder of the newspaper al-Nafeer and its weekly supplement in Hebrew Hashofar ${ }^{18}$; Mikhail Naimy (1889-1988), the Lebanese Arab Nahda leader in the Mahjar and a founding member of al-Rabitah al-Qalamiyah ${ }^{19}$; Nasib Arida (1887-1946), the Mahjar poet from Syria, along with his countryman Abd al-Massih Haddad (1888-1963); and Emile Touma (1919-1985), the Palestinian communist leader. This is precisely where the experiences of Khalīl Baydas and Iskandar al-Khūrī al-BeitJâli are relevant. They both lead us to the Russian educational enterprise in Palestine (1882-1914) along with the Arab-Palestinian Nabda movement.

The Imperial Orthodox Palestine Society (IOPS) was founded in 1882 and by 1914 had built 114 schools attended by 10,000 students, girls and boys alike. The Russians made a strategic decision to focus most of their activities outside the main urban centres of Jerusalem, Jaffa and Haifa, ${ }^{20}$ a decision which was motivated by the need to avoid tension with the Greek Patriarchate. The founder of the IOPS, Vassili Nikolaïevitch Khitrovo, wrote in December 1882: "We will open a school, if possible - some distance away from the Patriarchate that could interfere if we are close to them. If we locate far away, they will pay less attention to us and that way we can move from north to south." 21 This explains why the first Russian school was established in al-Mujaydil, outside Nazareth. By the time the IOPS closed in 1914, they had built some 19 educational institutions in the Galilee. Arabic language and culture, along with Palestinian culture and history were part of the curriculum. This was due to a number of considerations, including the contribution of Russian specialists such as Ignati Kratchkovski (1883-1951) and the indigenous Arabic output initiated by the Nahda pioneers led by intellectuals

\footnotetext{
${ }^{17}$ Hanna Abu Hanna, The Pioneers of the Nabda in Palestine (the Graduates of the Russian Schools) 1862-1914 (Beirut: Institute for Palestine Studies, 2005), 193 (in Arabic); Hanna Abu Hanna, The Russian Seminar in Nazareth (1886-1914) and the Cultural Revival in Palestine (Nazareth: Ministry of Education and Culture, Israel, 1994), 159. (In Arabic).

${ }^{18}$ Samir Toubassy, My Nakba: A Palestinian's Odyssey of Love and Hope (Ithaca, NY: Olive Branch Press, 2019), 256.

${ }^{19}$ The Pen League was the first Arab literary society based in North America (New York), established in 1920 by Michail Naimy, Khalil Jibran, Nassib Arrida and Abdu al-Masih Haddad.

${ }^{20}$ Omar Mehameed, Chapters on the History of Russian-Palestinian Society's Schools in Palestine (1882-1814) (Taibeh: Marqaz Ihia al-tourath al-Arabi, 1988), 188. (In Arabic).

${ }^{21}$ Hanna Abu Hanna, The Russian Seminar in Nazareth (1886-1914) and the Cultural Revival in Palestine (Nazareth: Ministry of Education and Culture, Israel, 1994), 23. (In Arabic).
} 
such as Butrus al-Bustani (1819-1883), Nassif al-Yaziji (1800-1870), Francis Marrache (1836-1873), Jurji Zaydan (1861-1914) and Jamal ad-Dîn al-Afghâni (1839-1897). ${ }^{22}$ To make up for the lack of Arabic teachers and to attract more local families, the IOPS opened two training seminaries, one for men in 1889 in Nazareth and the second for women in 1890 in Beit Jala. ${ }^{23}$

As to the Palestinian Nabda, the genesis of the Arabic Palestinian press is the work of many of the attendees of these Russian schools. The private Palestinian Arabic press was established in the immediate aftermath of the Young Turks' revolution in 1908. More than 30 newspapers appeared in 1908 in the Sanjaks of Jerusalem, Nablus and Acre, ${ }^{24}$ creating a new dynamic which promoted a unifying Arab nationalism at a time when this region was already undergoing administrative and confessional change. ${ }^{25}$ The most important among these journals were al-Quds (Jerusalem), al-Carmel (after Mount Carmel), al-Nafir (The Clarion) and al-nafa'is al-'asriyyah (The Modern Treasures) and later, in 1911, the leading political newspaper Falastin (Palestine). Moreover, the press continued to develop under the British Mandate during which 220 Arabic-language titles came into being between 1919 and 1948, such as Hayfa (Haifa, 1920), al-Jazeera (The Island, 1924), Yarmouk (1924) in Haifa; al-Kifah (The Arab Struggle, 1935 ) in Jaffa; Lisan al-Arab (The Language of the Arabs, 1921), al-Sabah (The Morning, 1921), Mir'aat al-Sharq (The Mirror of the East, 1919) in Jerusalem and al-Ittibad (The Union), an organ of the Communist Party. ${ }^{26}$ Khalī Baydas established an-nafa'is Al-Assriyyah in which he, along with Iskandar al-Khūrī al-BeitJālī, published translations of Russian literature and shared their love for it, particularly in the form of the trend towards literary realism which impacted their aesthetic literary orientation.

\section{Khalīl Baydas and the Foundation of Norms of the Palestinian Novel}

"The true, ingenious and skilled novelist is the one who lives, writes and dies for art" Khalīl Baydas, Masārih̆ Al-Adhān, 1924. The intellectual achievements of Khalìl Baydas as an $a d \hat{\imath} b$ are in line with the classic nabdawi

\footnotetext{
${ }^{22}$ Abu Hanna, The Pioneers of the Nahda in Palestine, 193; Mehameed, Chapters on History of Russian-Palestinian Society's Schools in Palestine, 188.

${ }^{23}$ The Russians also had ambitions to open a university in Syria, but the First World War put an end to this enterprise. Mujaydil was the first school in 1882. Mehameed, Chapters on History of Russian-Palestinian Society's schools in Palestine, 188.

${ }^{24}$ Emanuel Beska, "Yusuf al-'Isa: A Founder of Modern Journalism in Palestine," Jerusalem Quarterly 74 (2018): 7-13.

${ }^{25}$ Jihane Sfeir-Khayat, "Historiographie palestinienne. La construction d'une identité nationale," Annales. Histoire, Sciences Sociales 60, no. 1 (2005): 35-52.

${ }^{26}$ Mustafa Kabha and Dan Caspi, The Palestinian Arab In/Outsiders Media and Conflict in Israel (London-Portland: Vallentine Mitchell, 2011), 246.
} 
meaning of the word, that is to say "a person of extensive learning, culture, and refinement who is versed in one or more branches of $a d a b$ and who serves as a model of good behaviour". ${ }^{27}$ It is equally significant to underline that in the colonial context of the nineteenth century the $a d \hat{\imath} b$ is also someone who commits himself to the national anti-colonial struggle.

Khalīl Baydas was the founder of one of the most important cultural and literary magazines in the Arab East, $A n$-Nafā' is - An-Nafā'is Al-Assriyyah, which should also be viewed as a guide to the political and historical context of the period. This journal belongs to the field of cultural studies, but also constitutes a major source of information on the period (the end of the Ottoman Empire and the early years of the British Mandate) and particularly on the sociological composition of Palestinian society, especially the Christian and Muslim elites and their collaboration with other Arab cultural centres. It also reveals the contribution made by Palestinians to the reform of the Arabic language in order to ensure its general use in schools. $A n$-Nafä'is Al-Assriyyah also reflects the influence of the nascent Palestinian nationalism, publishing stories which illustrated the political experiences of its founder, Khalīl Baydas. In 1920, he was arrested and sent to Akka prison after his speech at the Nabi Musa Festival, where he addressed a crowd of Christians and Muslims in a highly politicised manner, arguing against the Balfour Declaration made by the British in 1917, which promised the Zionist Movement a homeland and the establishment of a Jewish State in Palestine. Hadith Sujūn (Letters from Prisons) confirms the strong link between national and cultural construction:

It was the 4th day of Nissan (April), the day of the arrival of Hebron's procession to Jerusalem to the celebrate the Prophet Musa's day, which is the great historical celebration of the Muslims in Palestine, in which Christians participate, especially in recent years, and which is dominated by patriotic spirit and has made the factors of separation between religions disappear. ${ }^{28}$

Baydas was born in 1874 in Nazareth, home to a large Christian community during the nineteenth and twentieth centuries. He attended the Russian Orthodox school and seminary where he mastered the Russian and Arabic languages and literatures, later becoming director of several Russian schools in Syria, Lebanon and Palestine. This experience allowed him to immerse himself in the cultural life of Beirut, Damascus and Cairo. In 1911, Baydas moved to Jerusalem to take up the role as a representative of Nazareth in the mixed council of the Palestinian Orthodox community; he also changed the name of his journal to An-Nafä'is Al-Assriyyah at this time. His life in

\footnotetext{
${ }^{27}$ Marlé Hammon, A Dictionary of Arabic Literary Terms and Devices (Oxford: Oxford University Press, 2018), 172.

${ }^{28}$ Khalīl Baydas, "Hadith al-Sujūn" (An-Nafã'is Al-Assriyyah)An-Nafä'is, July 10, 1920, Year 7, Part 18, Jerusalem. (In Arabic).
} 
Palestine ended tragically in 1948, when he escaped the terror of Haganah groups in the Jerusalem's Baqaa area but died the following year in Beirut.

Khalīl Baydas wrote and published novels, short stories, dictionaries, historical books on Arabs and on the Russian Tsars, articles on education, literature and politics and textbooks for Arabic learners. ${ }^{29}$ More importantly he also translated Russian literature. ${ }^{30}$ Indeed, Palestine was an important centre for Arabic literary translation and this is strongly linked to the establishment of European missions from the nineteenth century onwards. It is particularly in the field of Arab-Russian literary translation that the Palestinians stand out. ${ }^{31}$ Unfortunately, many of Baydas' books were, according to the Israeli jargon, "lost" or "abandoned" 32 in 1948. His most significant surviving achievement was therefore the establishment of $A n$-Nafā'is Al-Assriyyah, ${ }^{33}$ the newspaper which is central to envisaging the debates that were necessary in the framework of Palestinian national construction. It also articulated social issues according to the target of the readers, be they Christian or Muslim. But more importantly for literary research, this newspaper allows us to trace literary texts and writers lost during the $1948 \mathrm{Nakba}^{34}$ It is reasonable to assume that $A n$-Nafä'is Al-Assriyyah was modelled after al-Hilal, a cultural journal established in Cairo in 1892 by Jurji Zaydan (1861-1914), in the sense that it served as a tool of education (family, religious and ethical), a space for translations, but also as a platform for publishing literary texts. Baydas published his first and only novel, al-Warith (The Heir) in his journal. The novel was published in its full version in 2011 as part of a project entitled A Series to Revive Palestinian Literary Heritage by Digital Publishing and Electronic Distribution, based in Ramallah, Palestine.

${ }^{29}$ Ahmed Omar Shahin, Khalīl Baydas 1874-1949 (Nablus: al-Jamiyah al-Ilmiyah al-Falistiniah, 1996), 27. (In Arabic).

${ }^{30}$ Khalil Baydas has been extensively studied from the translation perspective by Spencer Dan Scoville. Scoville, Spencer, "The Agency of the Translator: Khalil Baydas' Literary Translations" (PhD diss., University of Michigan, 2012).

${ }^{31}$ Hussam Al-Khatib, Palestinian Translating Activity from the Renaissance to the 20th Century (Beirut: Makaz al-Arabia Lidirassat wa al-Nashr, 1995), 262. (In Arabic).

${ }^{32}$ During my research work at the National library of Jerusalem, I came across books with the sign "AP" which stands for "Abandoned property". These are the archives of Palestinians who fled the Haganah troops and were never able to retrieve their homes and property. They were added to the collection of the National Library of Israel and never returned to their original owners (Amit Gish, "Salvage or Plunder? Israel's 'Collection' of Private Palestinian Libraries in West Jerusalem," Journal of Palestine Studies XL, no. 4 [Summer 2011]: 6-23).

${ }^{33} A n$-Nafã 'isAn-Nafã'is Al-Assriyyah allows scholars in cultural studies to keep track of several literary texts and writers lost during the 1948 Nakba.

${ }^{34}$ In his essay شخصيات من الناصرة (Figures from Nazareth), Ahmed Marwat brings to light important intellectual and religious figures of the city. Among them are female personalities such as the great researcher of Arabic culture Kalthoum Nasr Oudeh (1892-1965), the journalist and radio host Asma Toubi (1905-1983), and Mai Mary Elias Zyadeh (1886-1941), the writer and poetess known for organising a weekly literary salon in Cairo that brought together the greatest cultural figures residing in the city. 
Al-Wārith was first partly published in 1919 in An-Nafä'is Al-Assriyyah. The novel is set on the eve of the First World War, but the events and characters are not centred on Palestine. Aziz al-Halabi, the main character, belongs to a Syrian family who settled in Egypt after the Damascus massacres of Christians in 1860. This information is disclosed quite early in the text and locates its main characters within a Christian identity. Aziz is the adopted son of his paternal uncle, Nuaaman al-Halabi, a successful merchant, which makes him his only heir. The main storyline is centred on Aziz's desire to emancipate himself from his social group and his family. Instead of marrying within his community, Aziz falls in love with Esther, a well-known Jewish dancer in Cairo, who increasingly demands large sums of money to pay for her lifestyle. She is supported by her aunt, Rachel, and other members of the Jewish community (who form the second main set of characters) to put pressure on Aziz in order to spend his uncle's money. The novel ends happily with Aziz marrying and loving Najla, a woman from his community, and becoming his uncle's heir. Although written in Baydas' beautiful Arabic rhetorical style, this novel is of limited aesthetic interest and more significantly, his address of Jewish characters is consistent with a mainstream anti-Semitism that identifies Jews with greed. Aziz is presented as a victim of a "Jewish plot". There is a multitude of Jewish characters helping Esther to extort money from Aziz. First comes the paternal Aunt Rachel, who is portrayed as the architect of the Machiavellian plan for the robbery. The latter calls on her friend Nathan whom she introduces as "from our community who defends all the interests of the people of Israel," Other characters who lend money, such as Aramia, Ashia and Rahab, are also involved. The novel's Christian characters are presented as honest and angelic, while the Jews are portrayed as diabolical. Salma Jayyusi rightly notes that the novel "offered a pejorative, Shylock-like view of Jews, depicting them as insatiably greedy for money and ready to commit any act of cruelty to obtain it". ${ }^{35}$ It is central to underline and expose this anti-Semitic orientation of this novel written within an Egyptian context, whereas BeitJālī's novel and those I mention below are rooted in this Palestinian geography and do not in any way subscribe to the plain anti-Semitism that is characteristic of $A l$-Wārith.

Realism as a genre is highlighted by the description by Baydas of the geographical and cosmopolitan context of Egypt, a country where he lived for several years. It is quite logical that Baydas chose a realist style of literature, as he was a translator of Russian realist authors. This realist tendency is very characteristic of early twentieth century Palestinian prose. Let's assume 1920 as a starting period of the Palestinian novel. ${ }^{36}$ Apart from Baydas and Iskandar al-Khūrī al-BeitJālī's novels, two other novels are known to have

\footnotetext{
${ }^{35}$ Salma Khadra Jayyusi, Anthology of Modern Palestinian Literature (New York: Columbia University Press, 1992), 14.

${ }^{36}$ Abu Hanna, The Russian Seminar in Nazareth, 159; Adel Usta, Readings in the Palestinian novellas (Ramallah: Ministry of Education, 2011), 188. (In Arabic).
} 
been published in $1920 .{ }^{37}$ One, Riwayat Miflih al-Ghassani, aw Safha min safhat al-Harb al-Alamiya al-Oula (The story of Miflah al-Ghassani or a chapter from World War I) is by Najib Nassar (1865-1948), the founder of the newspaper al-Carmel. ${ }^{38}$ It was first published in his newspaper and it bears an autofiction form. The main character, a writer from a Christian background, is a deserter who resisted the mandatory conscription ordered by the Ottomans during the First World War. It is noteworthy that Nassar himself went into hiding during this period after opposing Turkey's entry into the war alongside Germany. The other novel, Dhulm al-Walidayn (Injustice to Parents), was written by Yohana Khalī Thikrat, the founder of Bethlehem magazine $^{39}$ and was published in 1920 in Bethlehem ${ }^{40}$ and in 1921 in AnNafä'is Al-Assriyyah. Unfortunately, no copies have yet been recovered to allow a stylistic study. ${ }^{41}$ Interestingly, Hanna Abu Hanna's research in the Israeli archives led to the discovery of a manuscript novel written by Khalaf Sabbagh, one of the directors of the Russian school in Maaloul. ${ }^{42}$ Titled Ghadat al-Nassira, it describes the events of World War I in Nazareth, again with the Christian community as its central theme.

There was therefore, at a time which marks the beginning of the British Mandate in Palestine, an enthusiasm for fictional writing, particularly literary realism, by authors from the Christian community, especially the Orthodox one. Three novels out of four examine Palestine and its major cities during WWI. Baydas here may not seem like the first person to publish a novel, or a novel about the reality of Palestine, but he is certainly the one who sought to give direction to this new style of writing. In 1924, the final year of publication of An-Nafä'is Al-Assriyyah, Baydas tried to set out the foundations of the modern Palestinian novel, particularly in relation to the European novel and its translation into Arabic:

It is obvious that the genre of novels in the West is full of good attributes. Ahead of us by many stages in this field, the West has contributed hundreds of thousands of skilled novelists who are undisputed masters of this genre. By translating them or imitating their style, we can provide our literature with treasure and beauty, and our writers with style, knowledge and art. (Khalīl Baydas, 1924) $)^{43}$

${ }^{37}$ Abu Hanna, The Russian Seminar in Nazareth, 159.

${ }^{38}$ Thanks to Hana Abu Hanna work, a copy of this novel was recovered from the National Library of Israel in Jerusalem and published in 1981.

${ }^{39}$ Established in 1919 as a monthly magazine by Yohana Khalil Thikrat and 'Issa al-Khoury Bandak, Bethlehem published articles on culture, history and education. The magazine was discontinued in 1921.

${ }^{40}$ Hamdi Sakkut, The Arabic Novel: Bibliography and Critical Introduction, 1865-1995 (Cairo: The American University in Cairo Press, 2000), 4014.

${ }^{41}$ Abu Hanna, The Russian Seminar in Nazareth, 159.

${ }^{42}$ The school was built in 1905 by the IOPS, https://zochrot.org/ar/booklet/53051.

${ }^{43}$ Allen, Essays in Arabic Literary Biography, 75. 
Furthermore, Baydas' text, "The Art of the Novel," provides guidelines for novelists. The two major elements he espouses are the need to nourish general culture and to be attentive to the people and their concerns so as to be able to address them. However, it appears in the same text that these guidelines and Baydas's writings are the outcome of a literary syncretism imported from European culture. Indeed, Baydas takes as a model the writers of the Enlightenment (Molière, Racine, Corneille), Romanticism (Hugo, Chateaubriand) and Realism (Balzac, Dickens, Tolstoy and Dostoevsky). Why not then approach Baydas as the figure who laid the foundation for the future generation of Palestinian novelist? We see the need to move the date of the creation of realist Palestinian literature earlier than the post-Nakba period to the first decades of the twentieth century. This was a parallel literary realism with which Iskandar al-Khūrī al-Beit)ālī experimented in his 1920 novel Life After Death.

\section{ISKANDAR AL-KhūRI AND PALESTINIAN Literary REALISM}

Iskandar al-Khūrī al-Beitjālī is particularly entwined with the development of the short story as a genre in Palestine.$^{44} \mathrm{He}$ was born in Ein Karem near Jerusalem in 1890 to an orthodox family from Beit Jala, where he attended primary school. He learnt French at the Salesian school in Bethlehem and later studied Arabic language and literature at the Russian Seminary boarding school in Nazareth. He taught Russian and French at the Beit Jala Seminary. Although he was well versed in literature, Iskandar al-Khūri studied law and became a magistrate in 1927 for the cities of Safad, Tiberias, Nazareth, Akka, Jerusalem and Bethlehem. He also worked as the head of the Court of Appeal in Jerusalem until he retired in 1945. After the Nakba, he fled from Jerusalem to Beit Jala and lived there until his death in 1973. Meanwhile, he worked as a legal adviser to the Red Cross in Bethlehem and Hebron and acted as an inspector for UNRWA's schools.

Most of al-Khūri's works were published after 1920. They include poetry, short stories, novels and translations from Russian and French. Iskandar al-Khüri excelled in shaping the local Palestinian literary fabric and the fabric of its novel. Although his novels and short stories bear different names for their main characters, he clearly borrowed from his personal experience to write his literature, as we can see from his novella Catherine (1912) and his novel Life After Death (1920).

From the very beginning, al-Khūri was involved in literary realism, and this is probably due to the influence of the Russian literary realism with which he was familiar from translating such works. In the introduction to his novel Life After death, al-Khūri-writes:

it is a historical and social novel to the Arab reader. It is about the great war and the impact of a dying ruler who forced young Syrian men to enrol in the army

${ }^{44}$ Abu Hanna, The Russian Seminar in Nazareth, 159. 
and executed the ones who didn't obey. It is about the bloody battles between the Allied powers, Axis powers, the peace treaty of the Dardanelles, up to the entry of Allenby into Jerusalem. It is also about the impact of the war on families, women and the destruction of social and family structures. ${ }^{45}$

The novel is set in the old city of Jerusalem with characters who are mainly Christians. It starts with Najib, the main character, writing a farewell letter to his young wife, Adelle, in which he informs her of his decision to volunteer to the Ottoman army during WWI, despite having previously been in hiding after receiving his conscription orders because he didn't want to leave his wife to starve. Najib had enjoyed a comfortable life which allowed him to write articles for Arabic newspapers in Egypt and Syria. The First World War has put an end to this and driven him into poverty, but he is going to fight for al-Watan (the homeland) and later Adelle will think that he died during the war. On his way to the join the Ottoman troops, he is arrested by the police and he taken to the front. However, the idea of al-Watan becomes realistic when we discover that Najib is in fact an important leader of the opposition to the Ottomans. After bloody battles, the novel ends happily when Najib recovers his identity and home, retrieves his wife, and resumes his old Jerusalemite life without the Ottomans.

The novel's details about the reality of Palestine during this period bring confusion to the genre of the text itself. It could be regarded as a historical autobiography that corresponds to the life of the author, as al-Khüri deserted the Ottoman army and went into hiding in his native village. In any case, it is certain that the novel provides knowledge about the life of the Christian community in Jerusalem and its surroundings, and the life of conscripts in the region. It includes chapters about the 1915 Gallipoli campaign as well as about the Arab struggle against the Ottomans, which is referred to in the novel by characters who actually played roles in the Great Arab Revolt of 1916. In the words of Adel Usta, there is a synergy between the influence of Russian literary realism which gives life to the political-historical reality of this region:

what is striking about the novel Life after death is the influence of international literature, such as Russian, French and English, on its author who read Pushkin, Leon Tolstoy and William Shakespeare. In his introduction, Iskandar al-Khūri mentioned these names and the novel is filled with wretched characters who remind us of the French writer Victor Hugo's Misérables. And al-Khūri did not throw away the literal tradition, as much as he wanted to write about the reality which also celebrates the wretched. And that was the Arab reality under Turkish rule in its last decade. ${ }^{46}$

\footnotetext{
${ }^{45}$ Iskandar al-Khūri al-BeitJāli, Life After Death (Jerusalem: Al-Raqamia, 2018) with an introduction by the author.

${ }^{46}$ Iskandar al-Khūri al-BeitJāli, Life After Death (Jerusalem: Al-Raqamia, 2018), with an introduction by Adel Usta.
} 
Al-Khüri excelled in the art of the novella. ${ }^{47}$ The short story Catherine was first published in 1912 in a collection titled Haqu'ंiq wa 'Ibar (Facts and Lessons) and then in 1913 was republished in An-Nafä'is Al-Assriyyah. Catherine, the main character, belongs to a Catholic family, was educated by the Sisters of St Joseph Church, and mastered French. She falls in love with Najib, ${ }^{48}$ a man from an Orthodox family, a writer and poet who has studied in Beirut. However, the leaders of the two churches place obstacles in the way of their love, ordering that each must marry within their community. In the end, Najib manages to bribe a priest and is able to marry his beloved.

In another short story, al-Shahādah fi-l-qarn al-ishrin (Testimony in the Twentieth Century), published in 1912 in An-Nafä'is Al-Assriyyah, Iskandar al-Khūrī al-BeitJālī also brings the Russian context to Palestine. A Russian prince travels to Syria in order to urge parents in the villages to send their children to Russia to study. This suggestion is not widely followed, and is in fact only fulfilled by Salma's family who decide to send her abroad. To romanticise the story, Salma falls in love with the prince's son and agrees to marry him. In this case, however, it is her family who objects, and Salma decides to commit suicide instead of marrying her cousin. The two short stories describe the reality of Palestine in its Christian form, but it is presented from the point of view of the modernisation of the family and from the influence of the Russians. In these texts, there is strong rhetoric for a construction of the modern Palestinian family. By exposing the corruption of the regional church, al-Khüri brings to light the willingness of the youth of the broader Sham region (the Levant) to free itself from religious restrictions.

\section{Conclusion}

The elements outlined above highlight the extent to which the Nahda combined with the Russian educational enterprise in Palestine to generate a vibrant Arab-Palestinian cultural life during the British Mandate. It is above all a question of the influence of several Christian personalities, particularly from the Orthodox tradition, in the making of what is recognised as Palestinian literature. Understanding this allows us to comprehend the setting of the Palestinian novel and novellas written, in the case of Baydas and al-Khüri, with the influence of the translation of the Russian literature. I argue that the birth of this literary genre, the novel, was at the crossroads of the influence of Romanticism and above all of European literary realism, although al-Khüri tends towards realism and Baydas towards Romanticism, but with a local aspect based on the Arabic language and cultural traditions. This can be observed in Khalil Baydas' willingness to produce works for teaching the Arabic language but also a dictionary. Baydas appears not

\footnotetext{
${ }^{47}$ Abu Hanna, The Russian Seminar in Nazareth, 159.

${ }^{48} \mathrm{Najib}$ in this novella is not the same autobiographical character as in Life After Death.
} 
so much as the first writer to have published a novel in Palestine, but as the guide to this new literary genre distinguished by realism. In this way, it is quite legitimate to consider Baydas as the driving force behind this trend, which is very present in Palestinian literature in general. Furthermore, by adopting a literary realism, the genesis of the Palestinian novel has been embedded in a link between history and fiction and in an intertwined circulation between literature and social sciences. There is yet a very long path to investigate the culture of Palestine before its historical destruction in 1948. One of the most important guides in this effort is An-Nafā'is Al-Assriyyah (1908-1914, 1919-1923), which is, in a way, the literary archive of this period.

\section{BIBLIOGRAPHY}

Al-Husayni, Ishaq Musa. Mudhakkirāt dajājah. Cairo: Dar al-Maarif, 1943. (In Arabic).

Al-Khatib, Hussam. Palestinian Translating Activity from the Renaissance to the 20th century. Beirut: Makaz al-Arabia Lidirassat wa al-Nashr, 1995. (In Arabic).

Al-Khūri, Iskandar al-BeitJāli. Al-ḩā̄ät ba'd al-maūt. Jerusalem: Al-Raqamia, 2018. (In Arabic).

Allen, Roger, ed. Essays in Arabic Literary Biography 1850-1950. Wiesbaden: Harrassowitz, 2010.

Baydas, Khalīl. "Hadith al-Sujūn" (An-Nafā'is Al-Assriyyah). July 10, 1920, Year 7, Part 18, Jerusalem (In Arabic).

—. Ahwal al-Istibdāed, An-Nafā'is, 1909. (Arabic).

- Masareeh Al-Adhan, Cairo, 1924. (Arabic).

—. Al-Wārith, Al-Raqamia, Jerusalem, 2011. (Arabic).

Beska, Emanuel. "Yusuf al-'Isa: A Founder of Modern Journalism in Palestine." Jerusalem Quarterly 74 (2018): 7-13.

Daoud, Sihām. "Interview with Emil Habibi." Contemporary Theater Review 3, part 2 (1995): 103-112.

El-Ariss, Tarek. The Arab Renaissance: A Bilingual Anthology of the Nabda. New York: The Modern Language Association of America; Bilingual edition, 2018.

Elias, Marie. "Palestinian Theater, the Bumpy History of a maturing Art." https:// www.paljourneys.org/en/timeline/highlight/10520/palestinian-theater.

Erde, Tamara. Looking for Zion. Film by Katuh Studio and 13 Productions. http:// www.film-documentaire.fr/4DACTION/w_fiche_film/52690_1.

Falastin vol. XXX, nos. 180-6435 (10.10.46). (In Arabic).

Gish, Amit. "Salvage or Plunder? Israel's 'Collection' of Private Palestinian Libraries in West Jerusalem.” Journal of Palestine Studies XL, no. 4 (Summer 2011): 6-23.

Greenberg, Ela. Preparing the Mothers of Tomorrow: Education and Islam in Mandate Palestine. Austin: University of Texas Press, 2010.

Hammond, Marlé. A Dictionary of Arabic Literary Terms and Devices. Oxford: Oxford University Press, 2018.

Hanna Abu, Hanna. The Russian Seminar in Nazareth (1886-1914) and the Cultural Revival in Palestine. Nazareth: Ministry of Education and Culture, Israel, 1994. (In Arabic). 
Talā' $i$ al-nabda fì falasțin: ( the Nabda in Palestine (the Graduates of the Russian Schools) 1862-1914. Beirut: Institute for Palestine Studies, 2005. (In Arabic).

Jahjooh, Mohammed Omar, and Omar Ismail. Al-sīnimāa al-Falsțiñia: Tārīh wa hawiya (The Palestinians Cinema: History... and Identity). Ramallah: Tibaq Publishing, 2018. (In Arabic).

Jayyusi, Khadra Salma. Anthology of Modern Palestinian Literature. New York: Columbia University Press, 1992.

Kabha, Mustafa, and Dan Caspi. The Palestinian Arab In/Outsiders Media and Conflict in Israel. London-Portland: Vallentine Mitchell, 2011.

Khalidi, Rashid. Palestinian Identity: The Construction of Modern National Consciousness. New York: Columbia University Press, 2010.

Khoury, Souhail. "Palestinian Music, Blending Levantine Sounds and the Power of Poetry." https://www.paljourneys.org/en/timeline/highlight/10526/ palestinian-music.

Marwa, Ahmed. Šahșīāt min al-Nāṣira (Figures from Nazareth). Akka: Aswar, 2009. (In Arabic).

Mattar, Philip. Encyclopedia of the Palestinians, Facts on File Library of World History Series. New York: Facts on File, 2005.

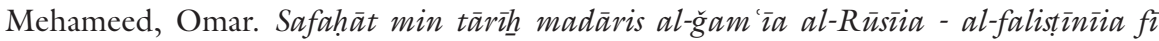
Falisțin (1882-1814). Taibeh: Marqaz Ihia al-tourath al-Arabi, 1988. (In Arabic).

Mrowat, Ahmad. "Karimeh Abbud: Early Woman Photographer (1896-1955)." Jerusalem Quarterly (Institute of Jerusalem Studies) 31 (2007): 72-78.

Nassar, Naj̄̄b. Riwāyat Miflih al-Ghassān̄̄, aw Safḥa min saf̣̂t al-Harb al-'Ālamiyya al-'Üla. Nazareth: Dar alSawt, 1920. (In Arabic).

Pappe, Ilan, The Rise and Fall of a Palestinian Dynasty: The Husaynis 1700-1948. Berkeley and Los Angeles: University of California Press, 2010.

Qustandi, Shomali. “Tradition et novation dans la littérature palestinienne: 19001948." Babel 7 (2003): 180-211.

Radai, Itamar. Palestinians in Jerusalem and Jaffa, 1948. London: Routledge, 2016.

Sadka, Noa. Ha-Emet ha-fotografit emet tiv'it hi: kronikah shel mablakah le-tsilum (Photographic Truth Is a Natural Truth-A Chronicle of a Photography Department). Tel Aviv: Resling, 2018. (In Hebrew).

Sakkut, Hamdi. The Arabic Novel: Bibliography and Critical Introduction, 1865-1995. 6-vol set. Cairo: The American University in Cairo Press, 2000.

Sfeir-Khayat, Jihane. "Historiographie palestinienne. La construction d'une identité nationale." Annales. Histoire, Sciences Sociales 60, no. 1 (2005): 35-52.

Shahin, Ahmed Omar. Khalīl Baydas 1874-1949. Nablus: al-Jamiyah al-Ilmiyah al-Falistiniah, 1996. (In Arabic).

Spencer, Dan Scoville. "The Agency of the Translator: Khalīl Baydas' Literary Translations." PhD diss., University of Michigan, 2012.

Tadros Khalaf, Noha. Les Mémoires de 'Issa al-'Issa - Journaliste et intellectuel palestinien (1878-1950). Paris: Karthala, 2009.

Tamari, Salim. "Jerusalem's Ottoman Modernity: The Times and Lives of Wasif Jawhariyyeh." Jerusalem Quarterly 9 (2000).

Toubassy, Samir. My Nakba: A Palestinian's Odyssey of Love and Hope. Northampton, MA: Olive Branch Press, 2019.

Usta, Adel. Qirāàt fì al-qișa al-qașīra al-falisținnia (Readings in the Palestinian novellas). Ramallah: Ministry of Education, 2011. (In Arabic). 
Open Access This chapter is licensed under the terms of the Creative Commons Attribution 4.0 International License (http://creativecommons.org/licenses/ by $/ 4.0 /)$, which permits use, sharing, adaptation, distribution and reproduction in any medium or format, as long as you give appropriate credit to the original author(s) and the source, provide a link to the Creative Commons license and indicate if changes were made.

The images or other third party material in this chapter are included in the chapter's Creative Commons license, unless indicated otherwise in a credit line to the material. If material is not included in the chapter's Creative Commons license and your intended use is not permitted by statutory regulation or exceeds the permitted use, you will need to obtain permission directly from the copyright holder. 